( Т. А. Роїк, д.Т.н., професор, П. О. Киричок, д.Т.н., професор, А. П. Гавриш, д.т.н., професор, О. С. Хлус, аспірантка, НТУУ «КПІ», Київ, Україна

\title{
ПОЛІПШЕННЯ ЯКОСТІ ПОВЕРХОНЬ ОТВОРІВ ЗНОСОСТІЙКИХ КОМПОЗИТНИХ ПІДШИПНИКІВ КОВЗАННЯ ПОЛІГРАФІЧНИХ МАШИН \\ ВРАХУВАННЯМ ДИНАМІЧНИХ КОЛИВАНЬ СИСТЕМИ «ВЕРСТАТ-ПРИСТРІЙ-ІНСТРУМЕНТ-ДЕТАЛЬ" ЗА УМОВ ТОНКОГО АБРАЗИВНОГО ШЛІФУВАННЯ
}

В статті представлені результати теоретикоекспериментального дослідження проблеми поліпшення якості поверхонь отворів зносостійких підшипників ковзання з нових високолегованих композитних матеріалів синтезованих на основі використання утилізованих та регенерованих відходів виробництва деталей 3 інструментальних сталей та нікелю типу 11РЗАМЗФ2, 7ХГ2ВМФ, 5ХВЗМФС, ХН55ВМТКЮ, ХН5ОВТФКЮ шляхом врахування динамічних коливань системи «верстатпристрій-інструмент-деталь" за умов тонкого абразивного шліфування. Досліджені схеми замкнутої динамічної системи шліфувального верстата, встановлені та розраховані передаточні функції процесу різання абразивним інструментом.

Розраховані похибки форми поверхні оброблення при тонкому абразивному шліфуванні новітніх композитів

з урахуванням дії реальних режимів різання за умов стабільності коливань системи «верстат-пристрій-інструмент-деталь". Показано, що динамічні коливання системи впливають на основні параметри якості поверхонь тертя - шорсткість $R_{a}$, ступеня наклепу $K$ та його глибини $h$.

Розроблені практичні рекомендації для промислового виробництва.

Ключові слова: тонке абразивне шліфування; режими різання; параметри шорсткості поверхні; ступінь наклепу; глибина наклепу; композиційні матеріали; динамічні коливання системи «верстат-пристрій-інструмент-деталь»; похибки поверхні; промислові рекомендації.

Постановка проблеми

У конструкціях новітнього обладнання поліграфічної техніки широко застосовують зно- состійкі композиційні матеріали, які одержані з цінної та дешевої сировини - промислових відходів високолегованих штампових

(๖) $2016 \mathrm{p}$. 


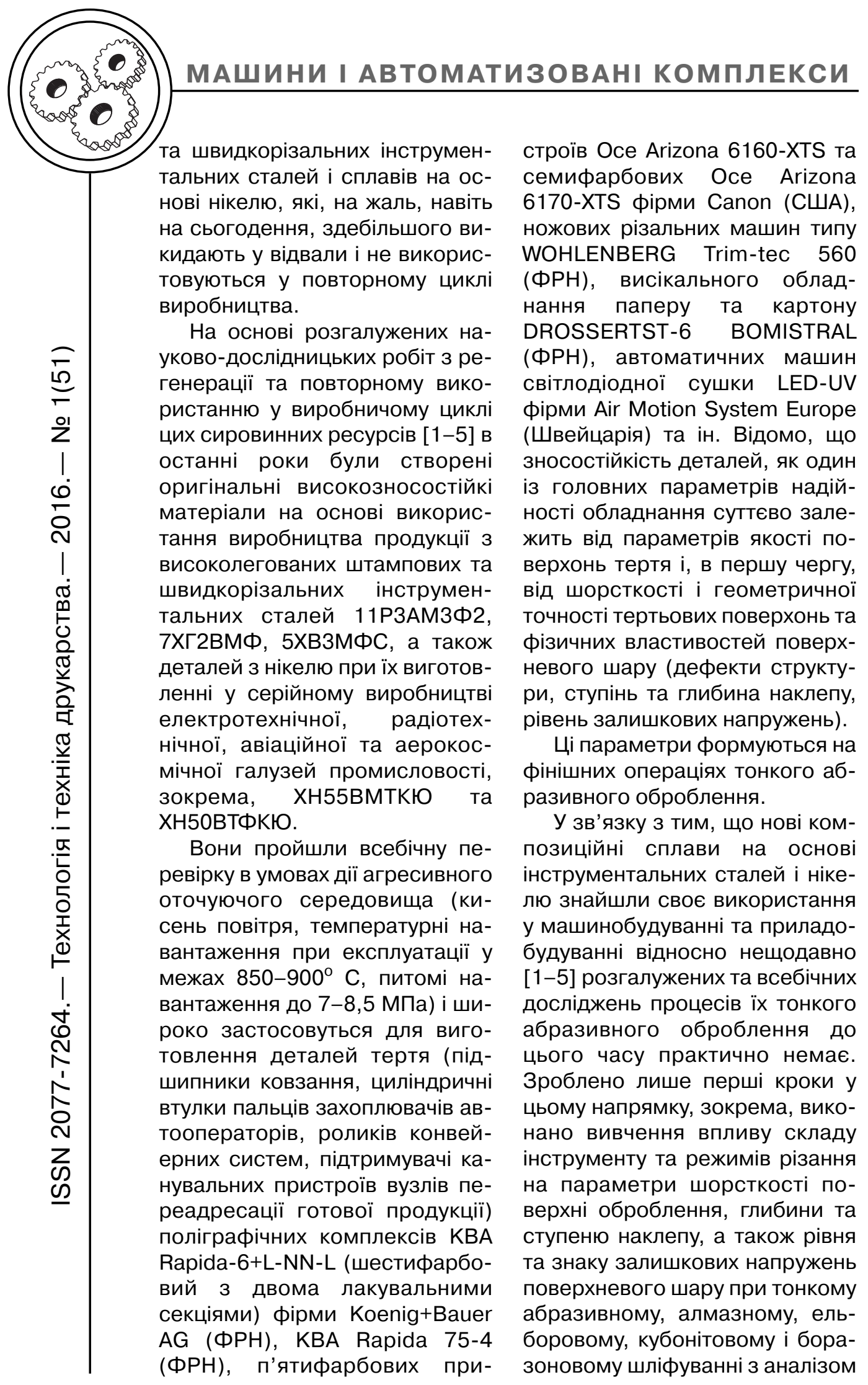


силових факторів різання та миттєвих контактних температур у зоні оброблення на ріжучому лезі поодинокого алмазноабразивного зерна [2, 4?8]. Крім того, були всебічно досліджені технологічні процеси оздоблювальної прецизійної доводки плоских поверхонь деталей тертя, а також оздоблювального суперфінішування та надтонкого викінчувального хонінгування деталей прецизійної точності для вузлів тертя поліграфічних машин, що виготовлені з новітніх марок високозносостійких композиційних матеріалів.

Проте на сьогодення залишаються недослідженими складні процеси, що супроводжують надтонку фінішно-оздоблювальну обробку прецизійних поверхонь тертя деталей поліграфічних машин, що суттєво впливають на їх якісні показники-параметри шорсткості і точності, глибини та ступеню наклепу, рівня та знаку залишкових напружень у поверхневому шарі деталі, якій було надано відповідну обробку 3 регламентованими режимами різання. Одним із таких факторів $€$ жорсткість системи «верстат-пристрій-інструмент-деталь» (ВПІД) та динамічні коливання цієї системи в ході реалізації технологічного процесу певної оздоблювальної обробки, що, безумовно, впливає на кінцеві результати оброблення. Слід особливо зазначити, що навіть, коли цей вплив (через показники шорсткості $\mathrm{R}_{\mathrm{a}}$ чи ступеню наклепу $\mathrm{K}$ і його глибини h) недостатньо суттєвий, необхідно брати до уваги усі фактори процесу у комплексі, бо на сьогодення у ряді випадків (наприклад, при оздоблювальному хонінгуванні, коли дослідники оперують з величинами $\mathrm{R}_{\mathrm{a}}$ у межах 0,005-0,010 мкм) покращення параметрів шорсткості поверхонь оброблення на 10-12 \% суттєво впливає на кінцеві значення одного з найважливіших показників надійності поліграфічної техніки довговічності, зносостійкості та ремонтоздатності, без досягнення високих значень яких неможливо витримати конкурентну боротьбу на сучасному рівні поліграфічної продукції.

Тому дослідження комплексу питань впливу динамічних коливань (вібрацій) систем ВПІД на якісні показники поверхонь тертя деталей $з$ високолегованих композитів за умови їх надтонкого алмазно-абразивного шліфування, безумовно, є актуальним питанням, що має незаперечне як наукове, так i, що не менш важливо, практичне значення.

\section{Мета роботи}

Метою цієї роботи було теоретико-експериментальне дослідження динамічних коливань (вібрацій) системи «верстатпристрій-інструмент-деталь» (ВПІД) при тонкому абразивному шліфуванні деталей прецизійної точності (зокрема підшипників ковзання), виготовлених 3 новітніх високозносостійких композиційних матеріалів на основі інструментальних сталей та нікелю, а також проаналізувати вплив динамічних коливань системи ВПІД на показники якості повер- 


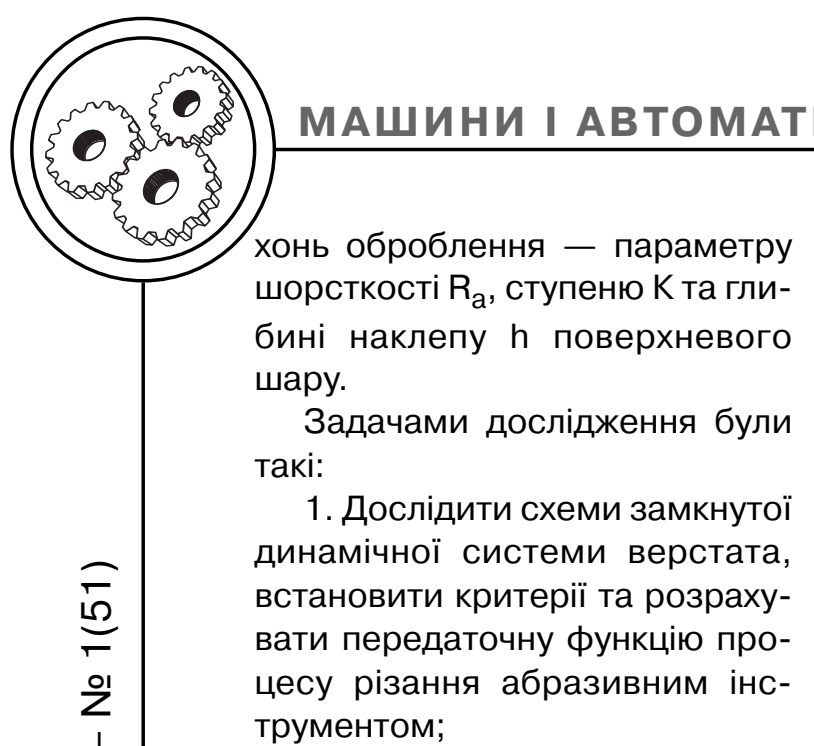

2. Проаналізувати пружню систему тонкого шліфування високолегованих композитних сплавів для поліграфічних машин за умови дії декількох відновлювальних елементів жорсткості;

3. Розрахувати похибки форми поверхні оброблення при тонкому абразивному шліфуванні новітніх композитів з урахуванням дії реальних режимів різання за умови стабільності коливань системи ВПІД;

4. Експериментально дослідити залежності фактичного зрізання шару композиту при призначенні реальних режимів різання для різних композитних сплавів за умови дії стабільних динамічних коливань системи ВПІД та визначити узагальнений комплексний показник тонкого абразивного шліфування високозносостійких високолегованих композиційних сплавів на основі інструментальних сталей та відходів виробництва деталей з нікелю.

5. Надати загальну оцінку впливу динамічних коливань системи ВПІД на параметри якості поверхонь оброблення (параметр шорсткості $R_{a}$, ступінь $K$ та глибина $\mathrm{h}$ наклепу поверхневого шару) за умов тонкого абразивного шліфування основних типів зносостійких композитів.

\section{Результати проведених досліджень}

При виготовленні композитних підшипників ковзання з високозносостійких композиційних матеріалів, що мають працювати у жорстких умовах експлуатації провідна роль у технологічному процесі належить шліфувальним операціям оброблення контактних поверхонь тертя [2, 5-7].

Суттєвий вплив на формування якості шліфувальної поверхні деталі мають вібрації, що виникають 3 різних чинників безпосередньо у процесі різання i, які супроводжують процес тонкого шліфування підшипника ковзання в ході усього технологічного процесу його виготовлення. На цю обставину вказують численні автори науководослідних робіт із загальної теорії абразивного оброблення [2, 6-24].

Як відомо $[20,21,23,24]$ рівень вібрації пружньої системи шліфувального верстату залежить від рівня зовнішніх збурень та безпосередньо ступеня жорсткості шліфувальної системи верстату, який $€$ самостійною, автономною, динамічною та замкненою багатофункціональною системою. На рис. 1 наведено принципову схему замкнутої динамічної системи верстату.

Процеси, які відбуваються у ході виконання технологічної операції зрізання певного шару композиту з поверхні оброблен- 


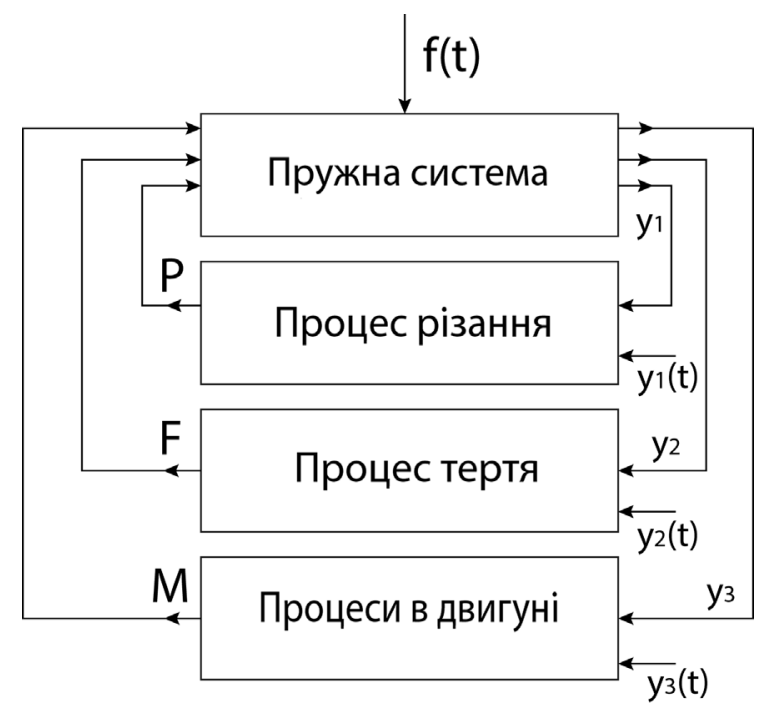

Рис. 1. Принципова схема побудови замкнутої динамічної системи шліфувального верстату. $1-\mathrm{y}_{1}, \mathrm{y}_{2}, \mathrm{y}_{3}$ - вихідні координати (деформація верстату); $2-\mathrm{y}_{1}(\mathrm{t}), \mathrm{y}_{2}(\mathrm{t}), \mathrm{y}_{3}(\mathrm{t})-$ зміна налаштування при змінах перерізу стружки az; 3 - P, F, M - збуджуючі фактори (сила різання P, сила тертя F, крутячий момент М двигуна)

ня деталі методом шліфування, безпосередньо пов'язані 3 пружньою системою і будь-які зміни у ній під впливом зовнішніх чинників (P, F, M) чи в результаті навіть конче необхідного переналаштування супроводжується реакцією пружньої системи, що обумовлює зміни ї̈ вихідних координат $\left(\mathrm{y}_{1}, \mathrm{y}_{2}, \mathrm{y}_{3}\right)$. Це обумовлює зміни параметру відповідної замкнутої динамічної системи, інакше кажучи, динамічна система верстату $€$ за своєю сутністю багатоконтурною з автоматичним регулюванням [20, 21, 23-27]. Дійсно, зі збільшенням, наприклад, припуску, що зрізається з поверхні композитної деталі абразивними зернами шліфувального кругу, зростають складові сил різання, які є вихідними координатами процесу, що негайно викличе зміни вихідної координати і відповідне зменшення величини припуску.

Суттєвий вплив на амплітудно-частотні характеристики пружньої системи мають характеристики її пружніх зв'язків. У шліфувальному верстаті усі процеси і перетворення (зрізання стружки, тертя контактних поверхонь зі своїми власними особливостями, крутильні процеси у електродвигуні) замикаються через притаманну лише даному верстату пружню систему. Тому з'являється можливість виділити (для подальшого аналізу) окремо кожен контур і розглядати його індивідуально.

Технологічні процеси тонкого шліфування композитних підшипників ковзання детально досліджені, а їх результати наведені у роботах [1-3, 5-7, 22]. 

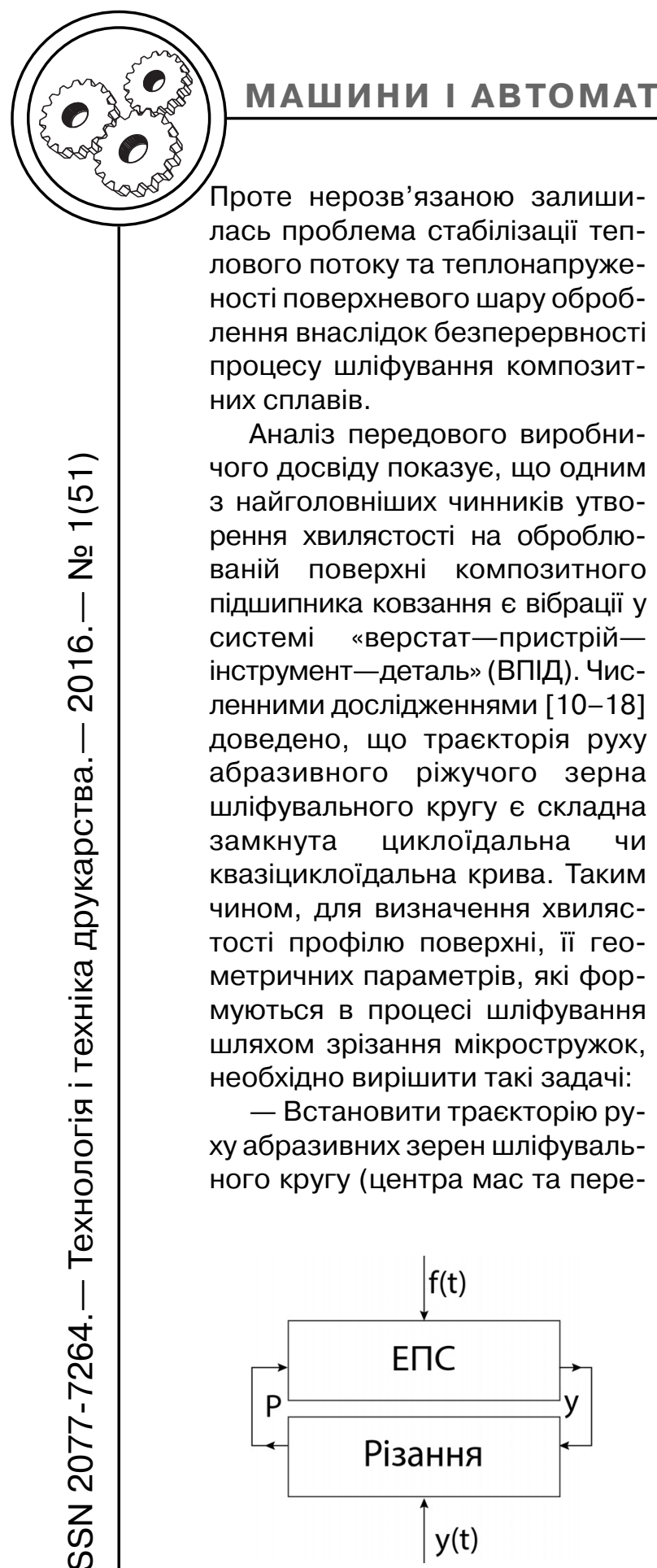

Рис. 2. Одноконтурна замкнута динамічна система. Р - сила різання на вершині ріжучого абразивного зерна; $f(t)$ - силове і кінематичне збурення; $\mathrm{y}(\mathrm{t})$ - зміна налаштування, що обумовлена зміною перерізу стружки

ферії) взаємодію її з оброблюваною поверхнею тертя композитного підшипника ковзання i надати математичний опис цього руху;

- Побудувати математичну модель, яка взмозі пов'язати динамічні параметри процесу 3 геометричними параметрами хвилястості.

Аналіз якості продукції в умовах реального виробництва дозволив дійти до висновку, що найголовнішими чинниками утворення похибок форми під час тонкого абразивного шліфування композитних сплавів $\epsilon$ вібрації елементів технологічної системи ВПІД, які виникають у процесі зрізання стружки абразивними зернами шліфувального кругу. Дослідження різних авторів [5, 8, 20-24] показали, що рівень вібрацій у підшипнику зменшується 3 покращенням параметрів шорсткості $\mathrm{R}_{\mathrm{a}}$ поверхонь оброблення.

Під час досліджень динамічних характеристик процесу різання було запропоновано розглядати взаємодію еквівалентної пружньої системи (ЕПС) верстату безпосередньо з процесом різання (рис. 2) [20]. Розмах вібрацій в цій системі залежить від збурюючих сил, що накладаються на систему $\mathrm{f}(\mathrm{t})$ і від зміни налаштування $-\mathrm{y}(\mathrm{t})$. Обидва види сил сприяють виникненню в процесі тонкого абразивного шліфування нових високозносостійких композитів на основі інструментальних сталей і нікелю складних вимушених коливань в системі ВПІД. В результаті цього 3'являється хвилястість як на ріжучій робочій поверхні шліфувального кругу, 
так і на поверхні оброблюваної деталі, що утворює у динамічній системі верстату зворотні зв'язки, які суттєво впливають на її стійкість.

Для ідеальної одноконтурної системи верстату без врахування зворотних зв'язків, що наведені на рис. 2, при впливі на еквівалентну пружню систему (EПC) $f(t)$ передаточної функції $\mathrm{W}_{\mathrm{f}}$ замкнутої системи визначаються за формулою $[20,21]$ :

$$
W_{f}=\frac{y}{f(t)}=\frac{W_{\text {fEEП }}}{1+W_{\text {роз }}},
$$

а при впливі $\mathrm{y}(\mathrm{t})$ :

$$
\mathrm{W}_{\mathrm{y}}=\frac{\mathrm{y}}{\mathrm{f}(\mathrm{t})}=\frac{\mathrm{W}_{\text {tEEП }}}{1+\mathrm{W}_{\mathrm{p03}}},
$$

де у - вихідна координата (деформація верстату); $W_{\text {fEпc }}-$ передаточна функція, що отримується в результаті зміщення інструменту і деталі за вихідною координатою при дії заданого зовнішнього збурення; $\mathrm{W}_{\text {роз }}$ передаточна функція розімкнутої системи, яка рівна $\mathrm{W}_{\mathrm{fEnc}} \cdot \mathrm{W}_{\mathrm{p}}$ $\left(\mathrm{W}_{\mathrm{fEnC}}\right.$ - передаточна функція $\mathrm{E} C \mathrm{C}, \mathrm{W}_{\mathrm{p}}$ - передаточна функція процесу різання).

В роботі [20] зазначено, що фактори запізнення в динамічній системі, викликані хвилястістю круга і деталі, які створюють зворотній зв'язок з відповідною передаточною функцією, значно ускладнюють рівняння передаточних функцій 1 і 2. Стійкість одноконтурної динамічної системи оцінюється за передаточною Функцією розімкнутої динамічної системи (рис. 3).

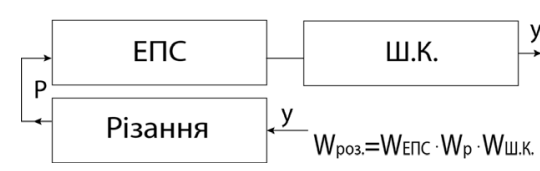

Рис. 3. Одноконтурна розімкнута динамічна система

Відмінною особливістю процесу шліфування $€$ те, що зв'язком між ЕПС і процесом різання в динамічній системі шліфувального верстату $€$ шліфувальний круг. Залежно від того, яку передаточну функцію він має $\left(\mathrm{W}_{\text {ш.к. }}\right)$, збурення, що виникають в процесі різання будуть передаватись на ЕПС з деяким запізненням і зміною за амплітудою, що може відобразитись на характері вібрації під час шліфування і на формуванні профілю поверхні деталі. Значення передаточної функції розімкнутої системи в даному випадку зміниться і опишеться формулою:

$$
\mathrm{W}_{\text {роз }}=\mathrm{W}_{\mathrm{E \Pi C}} \cdot \mathrm{W}_{\mathrm{p}} \cdot \mathrm{W}_{\text {ш.к. }}
$$

Це може змінити зони роботи пружної системи верстату (3). Визначення динамічної характеристики шліфувального круга (передаточної функції) $€$ важливим під час шліфування кругами з переривчастою робочою поверхнею, що є джерелом вимушених коливань.

В результаті оброблення осцилограм, записаних при динамічній характеристиці шліфувального круга, не було помічено зміни фаз між сигналами, що були зняті 3 периферії круга [9-12, 21]. Відношення амплітуд відповідних сигналів прирівнювалось одиниці технологічної системи $\mathrm{W}_{\text {ш.к. }}=1$. Це додатково 


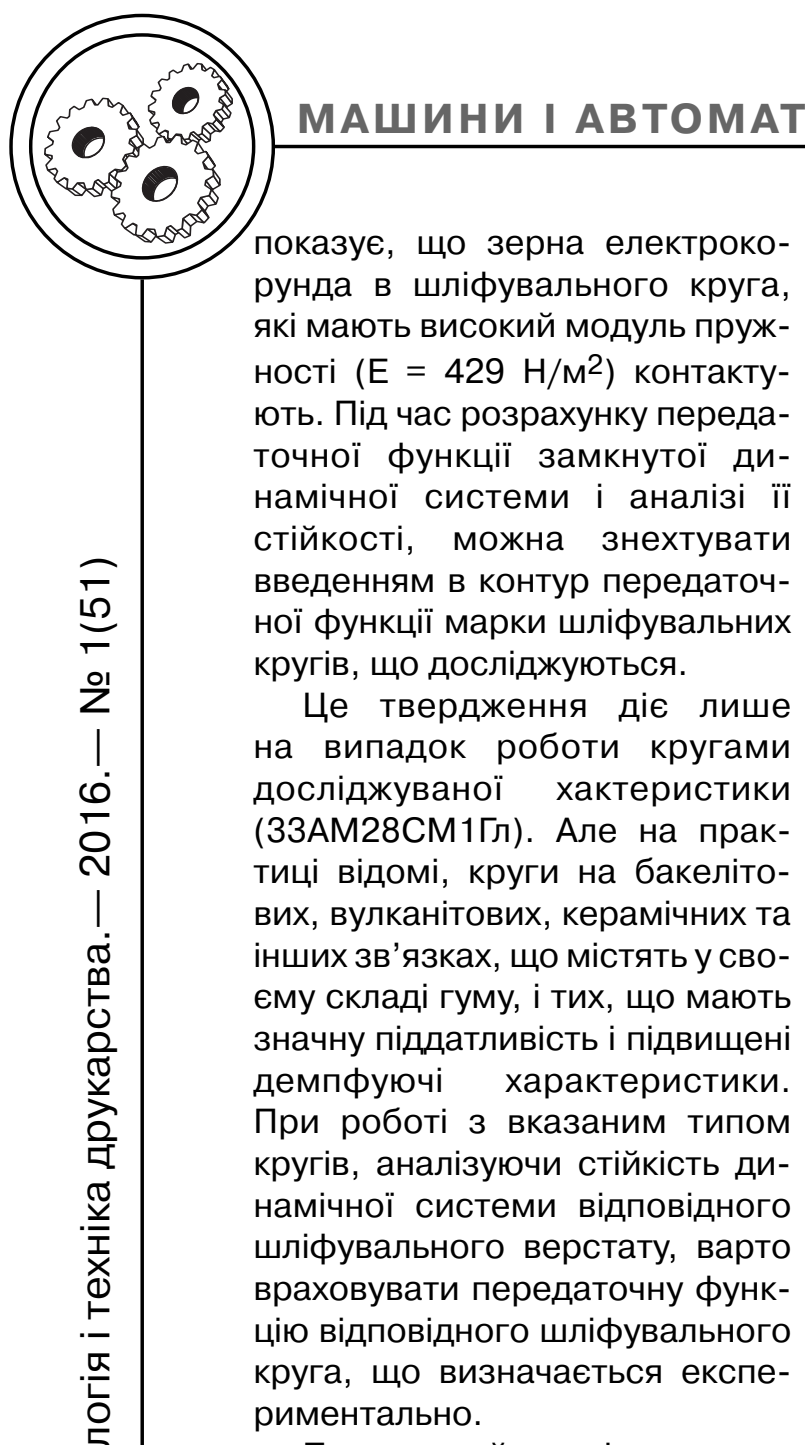

Проведений аналіз показав, що при виборі розрахункової схеми пружної системи шліфувального верстату можна знехтувати розгляд шліфувального круга як пружної ланки, що передає силу різання.

Для розроблення загальних рекомендацій з оптимізації геометричних параметрів переривчастих кругів запропоновано узагальнений показник процесу шліфування - K, що імітує дію вертикальної складової сили різання на пружню систему. Цей показник визначається режимами шліфування, станом робочої поверхні шліфувального круга, оброблюваністю композитного матеріалу і умовами взаємодії круга і деталі.

Під час розгляду стану рівноваги пружної системи в період контакту шліфувального круга 3 оброблюваною деталлю показник К вводиться в розрахункову схему як пружний відновлювальний елемент жорсткості. Таким чином, фізичним значенням введеного показника є сила різання, що приходиться на одиницю глибини врізання шліфувального круга в матеріал. При цьому враховувалась лінійна залежність сили різання від глибини шліфування (рис. 4, пряма 2), допустимість якої зумовлена відомими дослідженнями [25, 26] по вимірюванні сил різання під час шліфування.

Розглянемо пружну систему, шліфувального верстату, маса якої $\mathrm{m}_{\text {пр }}$ знаходиться під дією двох пружних відновлюваних елементів жорсткості С і K (рис. 4). Жорсткість С характеризуе властивості пружної системи верстату в розімкнутому стані і визначається конструкцією, а також умовами спряження ії̈ елементів один з одним. В розімкнутому стані, при відсутності процесу шліфування, переміщення пружної системи залежно від прикладеної сили q = $=\mathrm{f}(\mathrm{P})$ зображається прямою 1 (рис. 4), при лінійній характеристиці жорсткості. Жорсткість пружної системи шліфувального верстату $є$ основним показником, що визначається піддатливістю пружної системи верстату, що викликана силою різання, і характеризує точність оброблення в процесі тонкого шліфування. 


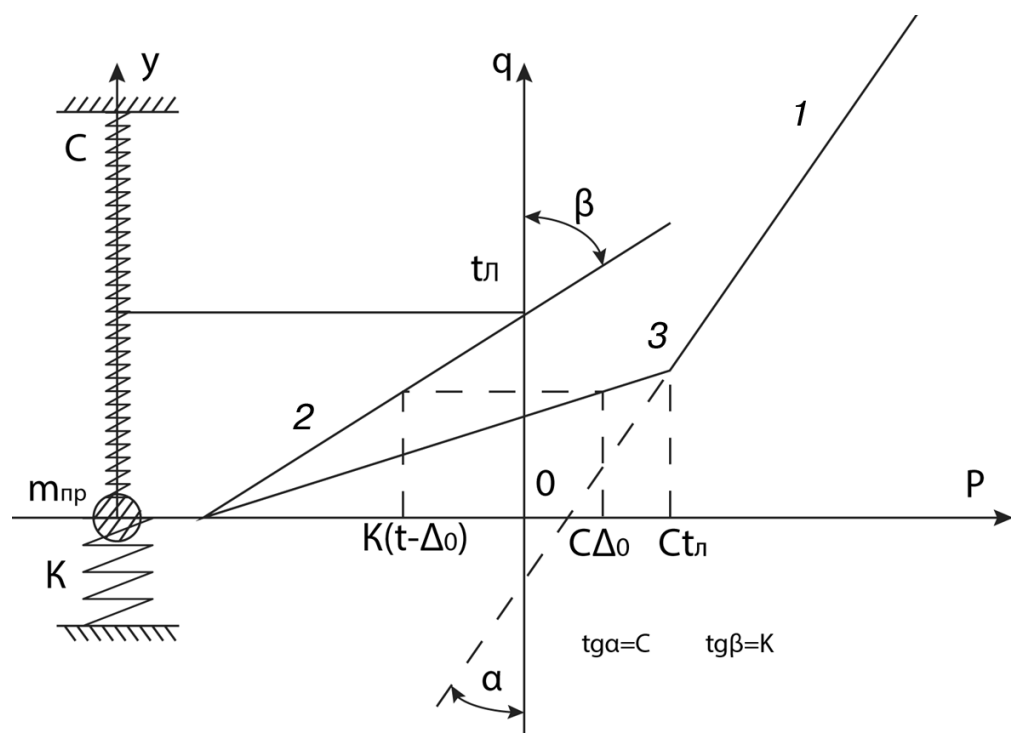

Рис. 4. Статичні характеристики пружної системи під час переривчастого шліфування

Встановимо зв'язок узагальненого показника з основними параметрами процесу шліфування і жорсткістю пружної системи верстату. Для подальших розрахунків найбільш прийнятною $є$ схема, що наведена у роботі [27]. Під час шліфування пружна система верстату замикається через процес різання [25], жорсткість її зростає і залежність сили різання від координат q характеризується прямою 3 (рис. 4).

Умова статичної рівноваги маси в процесі суцільного шліфування буде визначатись рівнянням:

$$
\mathrm{C} \Delta_{\mathrm{O}}=\mathrm{K}\left(\mathrm{t}_{7} \cdot \Delta_{\mathrm{O}}\right) \text {, }
$$

де $\Delta_{\mathrm{O}}-$ статичне відтиснення пружної системи при суцільному шліфуванні; $\mathrm{t}_{л}$ - глибина різання, що встановлюється за лімбом верстату.
Величина $\Delta_{\mathrm{o}}=\frac{\mathrm{K}}{\mathrm{C}+\mathrm{K}} \cdot \mathrm{t}_{л}$ характеризує похибку оброблення під час шліфування. При наступному проході вона буде вихідною глибиною шліфування, встановленою за лімбом верстату, і похибка після цього наступного проходу визначається за формулою:

$$
\Delta_{\mathrm{O}}=\left(\frac{\mathrm{K}}{\mathrm{C}+\mathrm{K}}\right)^{\mathrm{i}} \cdot \mathrm{t}_{\pi}
$$

де і - число переходів.

Аналіз (5) показує, що жорсткість пружної системи шліфувального верстату є основним параметром, що характеризує точність оброблення в процесі тонкого шліфування. Чим більше С, тим менше $\Delta_{\mathrm{O}}$. При C >> K похибка процесу шліфування прямує до нуля.

Знайдемо 3 формули (4) значення реального зрізання при- 


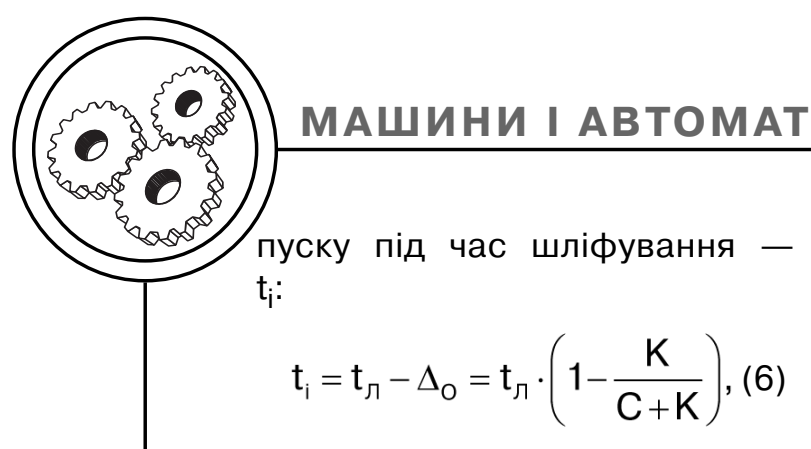

яке на наступних проходах розраховується за формулою:

$$
t_{i i}=\left(\frac{K}{C+K}\right)^{i-1} \cdot\left(1-\frac{K}{C+K}\right) \cdot t_{л}
$$

3 формули (6) узагальнений показник шліфування може бути знайдений за формулою:

$$
K=C \cdot\left(\frac{t_{ת}}{t_{i}}-1\right) .
$$

Вертикальна складова сили різання $\mathrm{P}_{\mathrm{y}}$ розраховується за формулою:

$$
P_{y}=K \cdot \frac{C}{C+K} \cdot t_{л} .
$$

Знаючи жорсткість пружної системи верстату і визначивши експериментально відношення $\mathrm{t}_{л} / \mathrm{t}_{\mathrm{i}}$ для кожного конкретного випадку шліфування, розрахунковим шляхом, 3 формули (8) можна знайти значення узагальненого показника шліфування.

Підставивши (8) в (9), отримаємо рівняння для визначення вертикальної складової сили різання $\mathrm{P}_{\mathrm{y}}$ :

$$
P_{y}=C \cdot\left(t_{л}-t_{i}\right) \text {, }
$$

що має важливе практичне значення, оскільки воно дозволяє при відомій статичній жорсткості пружної системи в вертикальній площині - C розрахувати силу різання $\mathrm{P}_{\mathrm{y}}$, провівши два вимірювання шліфувальної деталі: до $\left(\mathrm{H}_{1}\right)$ і після $\left(\mathrm{H}_{2}\right)$ шліфування.

При відомій глибині шліфування, встановленій за лімбом верстату $\left(t_{л}\right)$, визначивши $t_{i}=$ $=\mathrm{H}_{1}-\mathrm{H}_{1}$ за формулою (10), можна розрахувати вертикальну складову сили різання $\mathrm{P}_{\mathrm{y}}$. Даний спосіб розрахунку не потребує застосування приладів, призначених для вимірювання сили різання, чи характеристик, через які вона може бути розрахована (крутний момент, потужність шліфування, амплітуди статичного відтиснення пружної системи тощо).

При дослідженні процесу переривчастого шліфування необхідно проводити визначення узагальненого показника K під час шліфування одного і того ж матеріалу залежно від різних геометричних параметрів шліфувального круга. Це пов'язано 3 тим, що відношення $\mathrm{t}_{л} / \mathrm{t}_{\mathrm{i}}$, буде змінюватись залежно від рівня коливань пружної системи, зумовлених різними параметрами абразивного круга. Тут, безумовно, корисним $€$ необхідність зауважити, що незалежно від різновидності технологічного процесу шліфування і типу застосованого для оброблення абразивного інструменту, безпосередньо процес шліфування, як процес різання, $є$ дискретним, тобто переривчастим шліфуванням, бо в процесі зрізання стружки приймає участь лише частина зерен кругу ( 10 \% від їх загальної кількості) [2, 5, 8-15].

Формула (8) дає уявлення про зміну умов взаємодії пере- 
ривчастого шліфувального круга з оброблюваною деталлю, що показано в зменшенні відношення і дії, за рахунок коливань пружної системи. Це призводить до зниження узагальненого показника шліфування при одночасному підвищенні виробничого процесу.

На рис. 5 показана залежність показника К від швидкості повздовжніх переміщень у верстаті, що отримана експериментально під час шліфування зразку 3 композиту 11РЗАМЗФ2. Значення $\mathrm{K}_{20} / \mathrm{C}$, відкладені на графіку, відповідають шліфуванню з повздовжньою подачею $\mathrm{S}=$ $=20 \mathrm{Mm} /$ хід, розраховані за формулою (8). Характер зміни кривої $\left(\mathrm{K}_{20} / \mathrm{C}\right)=\mathrm{f}\left(\mathrm{V}_{\mathrm{B}}\right)$ можна пояснити наступним чином.

3 підвищенням швидкості переміщення деталі зростає сила різання $\mathrm{P}_{\mathrm{y}}$, і статичне відтиснення пружної системи, наслідком якого $є$ зростання відношення $t_{л} / t_{i}$ i різке збільшення коефіцієнта $\mathrm{K}_{20} /$ C. Починаючи зі швидкості 45 м/с круг починає працювати в режимі інтенсивного самозаточування, що знижує сили різання i збільшує зняття матеріалу. При цьому спостерігається наступне монотонне зростання показника шліфування, що зумовлено можливостями розміщення зрізаної стружки в міжзерновому просторі на поверхні круга.

Прийнявши лінійну залежність узагальненого показника К від повздовжньої подачі під час шліфування, значення можна знайти за формулою:

$$
\mathrm{K}_{\mathrm{S}}=\mathrm{K}_{20} \cdot \frac{\mathrm{S}}{20} \text {, }
$$

де $\mathrm{K}_{20}$ - узагальнений показник різання при шліфуванні 3 повздовжньою подачею 20 мм/хід;

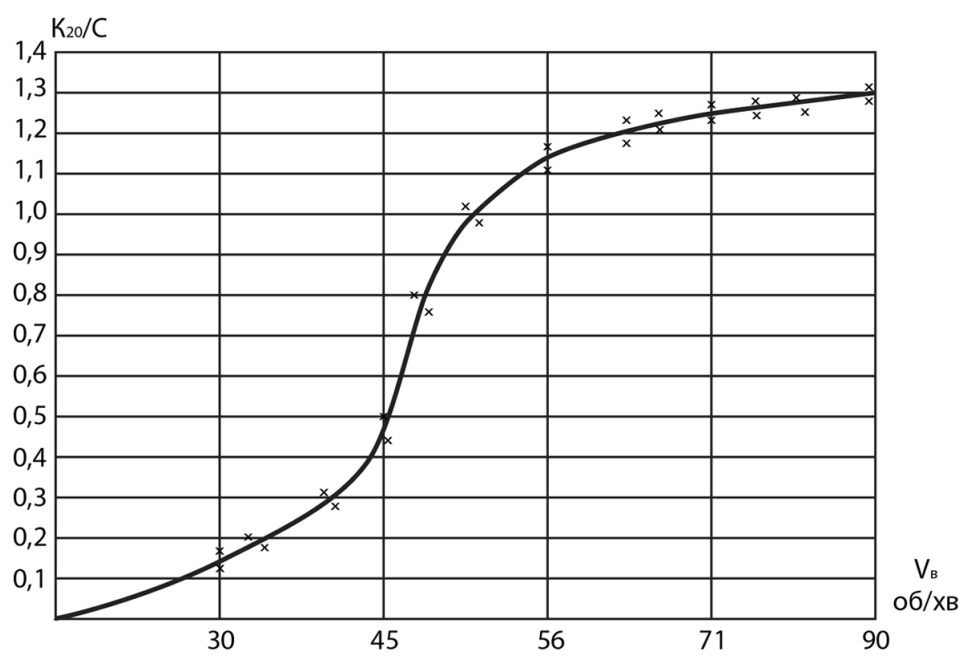

Рис. 5. Залежність коефіцієнта $\mathrm{K}_{20} / \mathrm{C}$ від швидкості переміщення (матеріал - композит 11РЗАМЗФ2), C = 1,11 · $10^{5} \mathrm{H} / \mathrm{M} . \mathrm{V}_{\mathrm{kp}}=45 \mathrm{M} / \mathrm{c}$, $\mathrm{K}_{\mathrm{S}}=\mathrm{K}_{20} \cdot \mathrm{S} / 20$, марка кругу - 33АМ28СМ1Гл 


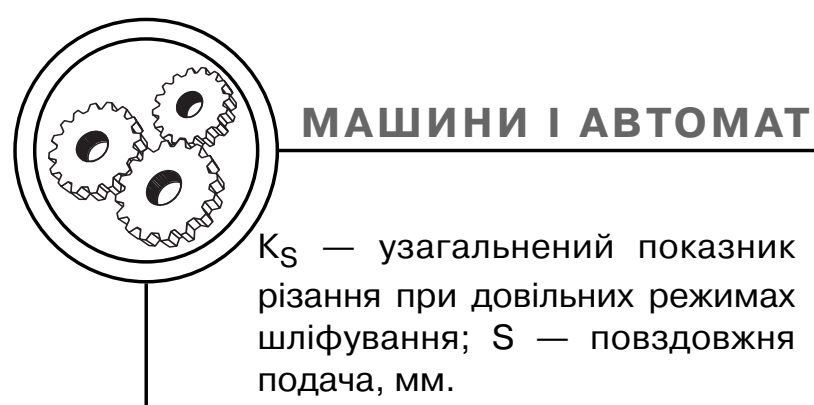

Проведені дослідження показали, що при різних поєднаннях фіксованих значень повздовжньої подачі - S і швидкості $\mathrm{V}_{\mathrm{B}}$ показник $\mathrm{K}$, що визначаються відношенням $\mathrm{t}_{\sqrt{Л}} / \mathrm{t}_{\mathrm{i}}$, не залежить від глибини шліфування t. Це положення підтверджує лінійність залежності $\mathrm{t}_{\mathrm{i}}=\mathrm{f}\left(\mathrm{t}_{\text {Л }}\right)$, що побудована на основі експериментальних даних для одного з можливих поєднаннях ширини шліфування і швидкості переміщення (рис. 6). Лінійність даної залежності зберігається при нормальних умовах шліфування, що застосовуються на практиці, під якими розуміється розміщення певної кількості зрізаної стружки в міжзерновому просторі на поверхні шліфувального круга.

За графіком (рис. 5) і формулою (11) визначається значення узагальненого показника для конкретних режимів шліфування. Варто зазначити, що показник К може бути загальною кількісною характеристикою ефективності процесу тонкого абразивного шліфування. Розрахунок для переривчастого шліфування доцільно проводити за формулою, аналогічною (8):

$$
K_{e \phi}=C \cdot\left(\frac{t_{Л}}{t_{e \phi}}-1\right)
$$

де $\mathrm{K}_{\text {еф }}$ - узагальнений показник шліфування при переривчастому шліфуванні; $\mathrm{t}_{\mathrm{e \phi}}-$ дійсна глибина різання при переривчастому шліфуванні.

Введений узагальнений показник шліфування $\mathrm{K}$ можна використовувати для оцінки роботоздатності абразивного інструменту, на рівні з такими показниками, як [5-7, 13, 21, 24]:

$$
p=\frac{Q_{M}}{Q_{d}} \text { чи } g=\frac{Q_{d}}{Q_{M}} ; p=C \cdot \frac{Q_{M}{ }^{2}}{Q_{d}} ;
$$

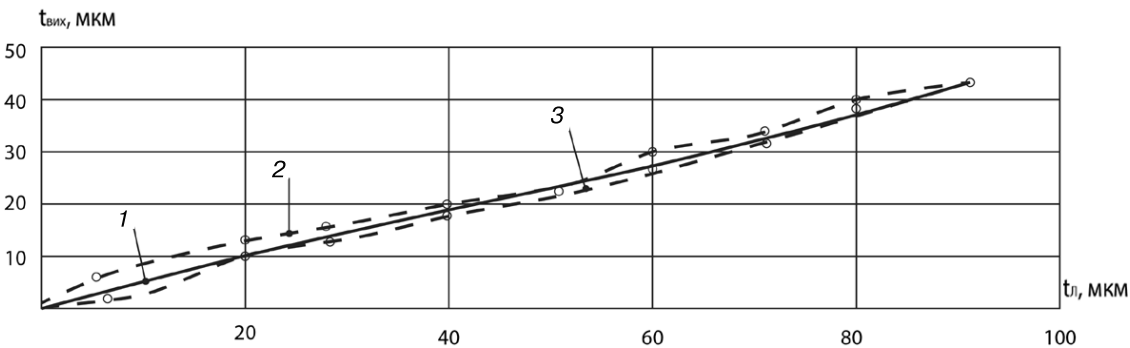

Рис. 6. Залежність фактичної товщини зрізаного шару композитного підшипника $\left(\mathrm{t}_{\text {вих }}\right)$ від глибини шліфування по лімбу верстата $\left(\mathrm{t}_{л}\right)$. Матеріал оброблення: 1 - композит на основі швидкорізальної сталі 11РЗАМЗФ2; 2 - композит на основі інструментальної сталі 7ХГ2ВМФ; 3 - композит на основі нікелю ХН55ВМТКЮ. Шліфувальний верстат SS-125 фірми «Werkzojt» (ФРН). Абразивний круг 3ЗАМ28СМ1Гл.

Режими різання: швидкість кругу $\mathrm{V}_{\text {кр }}=45 \mathrm{~m} / \mathrm{c}$, швидкість виробу

$$
\mathrm{V}_{\mathrm{B}}=45 \text { об/хв., подача } \mathrm{S}=20 \text { мм/хід }
$$




$$
\mathrm{G}=\frac{\mathrm{P}}{\mathrm{N}_{\text {пит }} \cdot \mathrm{R}_{\mathrm{a}}} ; \mathrm{M}=\frac{\mathrm{Pz_{ \text {пит } }}}{\mathrm{g}} ; \mathrm{N}=\frac{\mathrm{Q}_{\mathrm{M}}}{\mathrm{P}_{\mathrm{y}}},
$$

де $Q_{M}, Q_{d}-$ об'єм знятого металу і зношеної частини абразиву за одиницю часу; С жорсткість системи; $\mathrm{N}_{\text {пит }}-$ питома витрата енергії; $\mathrm{R}_{\mathrm{a}}$ - висота шорсткості; $\mathrm{Pz}_{\text {пит }}$ - питома тангенціальна сила.

Недоліком перерахованих показників оцінки роботоздатності шліфувальних кругів і необхідність визначення їх для різних можливих поєднань режимів шліфування і складність вимірювань величин, за якими вони розраховуються. Встановлений зв'язок введеного показника $\mathrm{K}$ з режимами шліфування дозволяє розраховувати його значеним для різних поєднань режимів шліфування. Експериментальне визначення К складається у вимірюванні дійсного зняття матеріалу деталі. Залежність показника $\mathrm{K}$ від часу шліфування показана на рис. 7.

На базі наведених даних були виконані дослідження впливу динамічних коливань системи ВПІД на основні показники якості поверхонь оброблення (параметр шорсткості $R_{a}$, ступінь наклепу $\mathrm{K}$ та глибина його проникнення $\mathrm{h}$ у поверхневий шар). Комплекс цих напрацювань здійснювавася у відповідності з методикою, наведеною у роботах [2, 5-8, 19-25].

Що стосується одного з найголовніших факторів зношування поверхонь тертя деталей пар

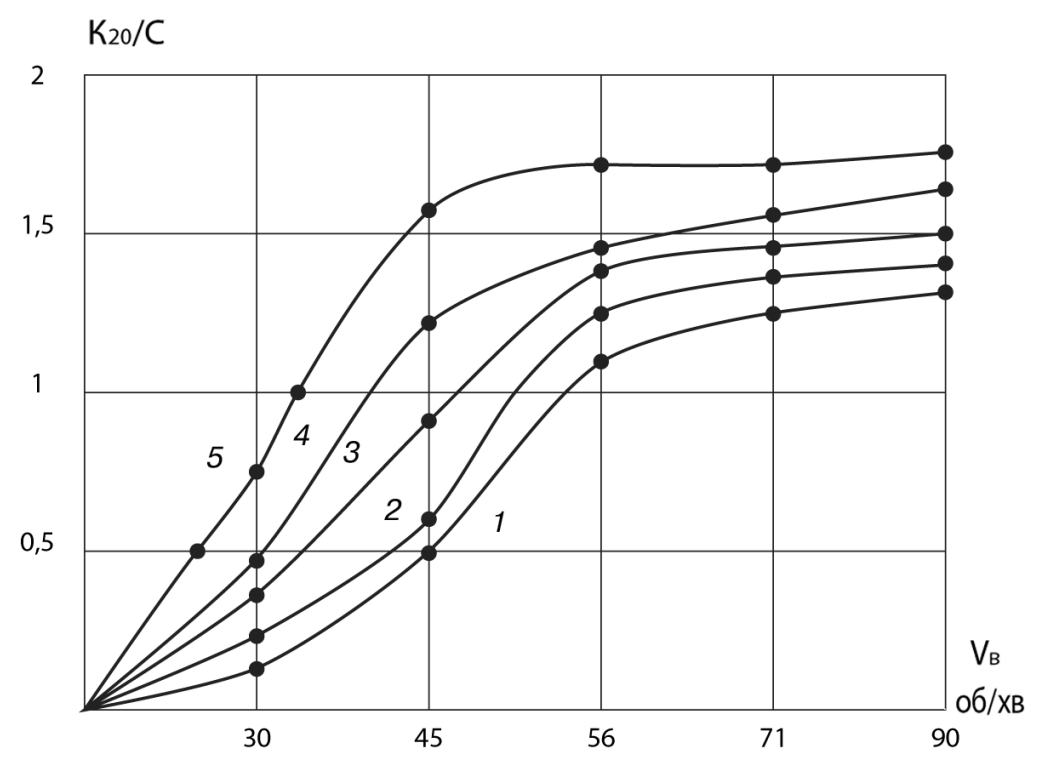

Рис. 7. Залежність коефіцієнта $\mathrm{K}_{20} / \mathrm{C}$ від швидкості обертання виробу $\mathrm{V}_{\text {в }}$ (матеріал композиційного сплаву на основі інструментальної сталі 7ХГ2ВМФ + (4-8) \% $\mathrm{CaF}_{2}$, подача $\mathrm{S}=20$ мм/об, $\mathrm{C}=1,09 \cdot 10^{5} \mathrm{H} / \mathrm{M}$ ) та довжини контакту Т ріжучого зерна з деталлю оброблення: $1-\mathrm{T}=10 \mathrm{c}$; $2-\mathrm{T}=15 \mathrm{c} ; 3-\mathrm{T}=30 \mathrm{c} ; 4-\mathrm{T}=45 \mathrm{c} ; 5-\mathrm{T}=60 \mathrm{c}$ 


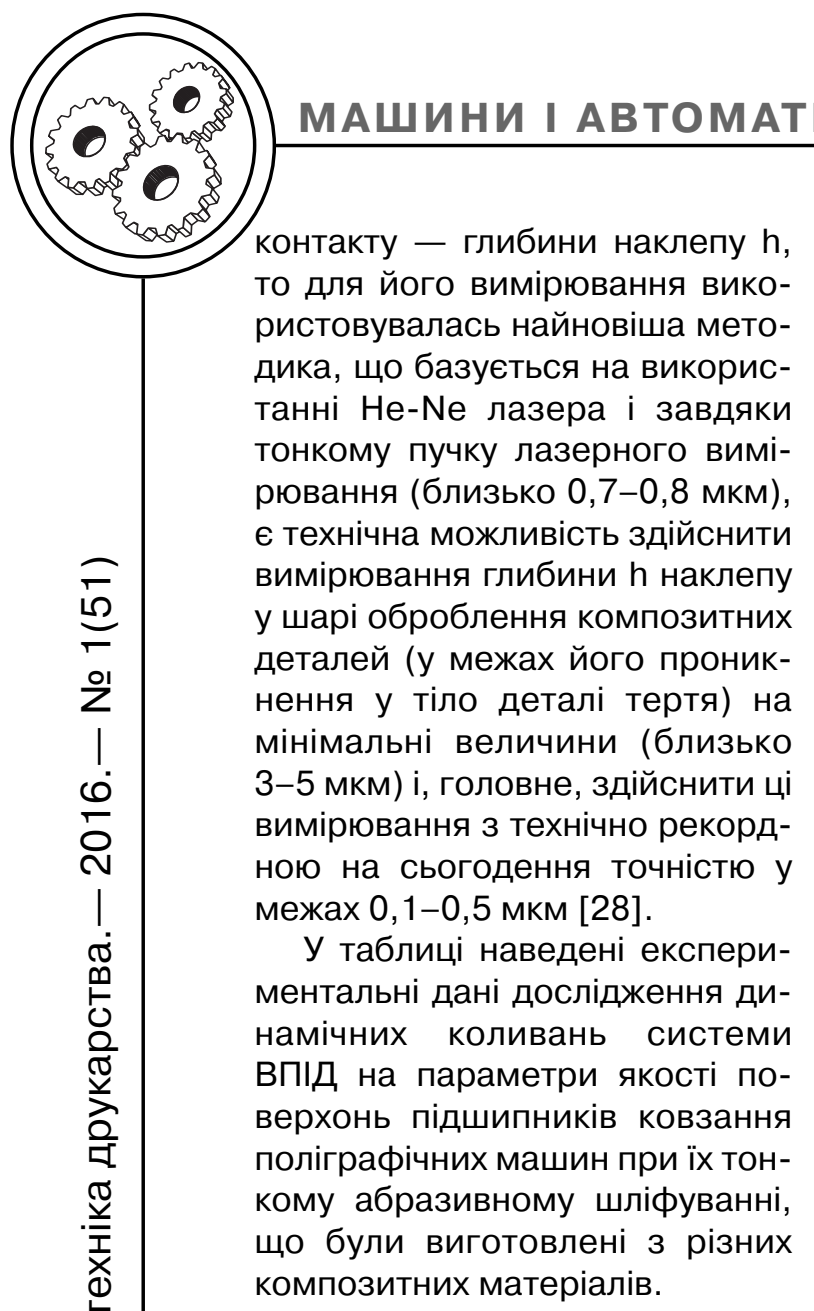

Аналіз табл. дозволяє зробити декілька важливих для промислової практики висновків і розробити ряд практичних рекомендацій, які створюють необхідні умови для організації продуктивної праці і отримання найліпшої якості оброблення поверхонь тертя підшипників ковзання сучасної поліграфічної техніки.

По-перше, встановлено, що частота динамічних коливань системи ВПІД суттєво впливає на всі основні показники якості поверхонь при їх тонкому абразивному шліфуванні, в першу чергу, на параметр шорсткості $\mathrm{R}_{\mathrm{a}}$. Ступінь наклепу $\mathrm{K}$ i глибини $\mathrm{h}$ його проникнення у тіло деталі оброблення.

По-друге, чітко прослідковується тенденція до погіршення параметрів $R_{a}$, K i h зі зрос-

Вплив частоти $t$ динамічних коливань системи ВПІД на параметри шорсткості $\mathrm{R}_{\mathrm{a}}$, ступеню наклепу $\mathrm{K}$ та глибини наклепу $\mathrm{h}$ поверхонь тертя підшипників ковзання поліграфічних машин зі зносостійких композитів при їх тонкому абразивному шліфуванні

\begin{tabular}{|c|c|c|c|c|c|c|c|c|c|}
\hline \multirow{3}{*}{$\begin{array}{c}\text { Частота } \\
\text { динамічних } \\
\text { коливань } \\
\text { системи } \\
\text { ВПІД, кГц }\end{array}$} & \multicolumn{9}{|c|}{ Параметри якості поверхонь для композитів } \\
\hline & \multicolumn{3}{|c|}{ 11РЗАМЗФ2 } & \multicolumn{3}{|c|}{ 7ХГ2ВМФ } & \multicolumn{3}{|c|}{ ХН55ВМТКЮ } \\
\hline & $\begin{array}{l}\mathrm{R}_{\mathrm{a}} \\
\text { MKM }\end{array}$ & $\mathrm{K}$ & h, MKM & $\mathrm{R}_{\mathrm{a}}, \mathrm{MKM}$ & $\mathrm{K}$ & h, MKM & $\mathrm{R}_{\mathrm{a}}, \mathrm{MKM}$ & $\mathrm{K}$ & h, MKM \\
\hline 0,05 & 0,270 & 1,22 & $8,1-9,0$ & 0,250 & 1,19 & $8,0-8,5$ & 0,290 & 1,17 & $7,5-8,0$ \\
\hline 0,10 & 0,275 & 1,23 & $9,1-9,2$ & 0,255 & 1,20 & $8,5-8,7$ & 0,295 & 1,18 & $8,0-8,5$ \\
\hline 0,20 & 0,280 & 1,25 & $9,2-9,3$ & 0,265 & 1,21 & $8,7-8,9$ & 0,300 & 1,19 & $8,5-9,0$ \\
\hline 0,30 & 0,300 & 1,27 & $9,4-9,5$ & 0,280 & 1,22 & $9,0-9,2$ & 0,301 & 1,21 & $9,1-9,3$ \\
\hline 0,50 & 0,320 & 1,29 & $9,6-9,8$ & 0,295 & 1,25 & $9,2-9,4$ & 0,315 & 1,24 & $9,3-9,5$ \\
\hline 0,80 & 0,350 & 1,31 & $9,9-10,0$ & 0,310 & 1,27 & $9,5-9,8$ & 0,325 & 1,27 & $9,6-9,8$ \\
\hline 1,00 & 0,380 & 1,32 & $10,1-10,3$ & 0,330 & 1,29 & $9,8-10,0$ & 0,335 & 1,31 & $9,9-10,1$ \\
\hline 1,50 & 0,410 & 1,35 & $10,4-10,5$ & 0,360 & 1,31 & $10,1-10,3$ & 0,370 & 1,33 & $10,2-10,4$ \\
\hline 2,00 & 0,470 & 1,37 & $10,6-10,9$ & 0,390 & 1,33 & $10,3-10,5$ & 0,410 & 1,38 & $10,5-10,8$ \\
\hline 2,50 & 0,510 & 1,50 & $11,0-11,5$ & 0,430 & 1,38 & $10,6-10,9$ & 0,440 & 1,45 & $10,9-11,2$ \\
\hline
\end{tabular}

Примітки: 1. Верстат ss-125 фірми «Werkzojt» (ФРН); 2. Абразивний інструмент шліфувальний круг 33АМ28СМ1Гл; 3. Режими шліфування - швидкість кругу $\mathrm{V}_{\mathrm{kp}}=45 \mathrm{~m} / \mathrm{c}$, швидкість виробу $\mathrm{V}_{\mathrm{B}}=45 \mathrm{~m} /$ хв., подача $\mathrm{S}=20 \mathrm{~mm} /$ хід, глибина різання $\mathrm{t}=0,020 \mathrm{~mm}$ 
танням частоти динамічних коливань системи ВПІД. Досліджень закономірностей цих змін на даному етапі наукових напрацювань не приводилось, бо це становить самостійну технологічну проблему, яку необхідно терміново вивчати з метою подальшого покращення параметрів оброблення при тонкому абразивному шліфуванні новітніх високозносостійких композитних матеріалів, спеціально створених для друкарської техніки і суттєвого збільшення на цій основі показників надійності, зносостійкості, довговічності та ремонтоздатності сучасних поліграфічних машин.

По-третє, вказана тенденція відзначається при шліфуванні різних марок зносостійких композитних сплавів, які мають достатньо різні фізико-механічні властивості і принципово різну структурну побудову [1-7].

Це свідчить про наявність загальної фізичної закономірності, яку, безумовно, необхідно всебічно дослідити і встановити відповідні залежності між факторами динамічних коливань системи ВПІД та параметри якості поверхонь оброблення з одночасною розробкою нормативів по режимам різання при тонкому абразивному шліфуванні новітніх марок високозносостійких композиційних сплавів.

З урахуванням наведених вище теоретичних досліджень вивчення динамічних коливань системи ВПІД та беручи до уваги попередньо отримані авторами результати експериментальних робіт про зв'язок між режи- мами різання та параметрами якості поверхонь оброблення доцільним $є$ прецизійне оброблення композитних підшипників ковзання друкарських машин методом тонкого абразивного шліфування з наступними режимами різання: шліфувальний верстат - SS-125 фірми «Werkzojt» (ФPH); абразивний круг - З3АМ28СМ1Гл; швидкість обертання шліфувального кругу - $\mathrm{V}_{\text {кр }}=45 \mathrm{M} / \mathrm{c}$; швидкість виробу $-\mathrm{V}_{\text {в }}=45$ м/хв., подача $\mathrm{S}=20$ мм/хід, глибина різання $\mathrm{t}=0,020 \mathrm{MM}$.

\section{Висновки}

Узагальнюючи комплекс виконаних досліджень необхідно зробити наступні висновки.

1. Вперше в науковій практиці виконано багатопланове теоретико-експериментальне дослідження поліпшення параметрів якості поверхонь тертя підшипників ковзання з новітніх високозносостійких композитних матеріалів на основі інструментальних сталей та відходів деталей з нікелю шляхом врахування динамічних коливань системи «верстатпристрій-інструмент-деталь» за умови тонкого абразивного шліфування.

2. Досліджені схеми замкнутої динамічної системи шліфувального верстата, встановлені критерії та розраховані передаточні функції процесу різання абразивним інструментом.

3. Розраховані похибки форми поверхні оброблення при тонкому абразивному шліфуванні новітніх композитів з урахуванням дії реальних режимів 


\section{МАШИНИ І АВТОМАТИЗОВАНІ КОМПЛЕКСИ}

різання за умови стабільності коливань системи ВПІД.

4. Показано, що динамічні коливання системи ВПІД впливають на параметри якості поверхонь тертя підшипників ковзання, при цьому ця залежність існує при тонкому шліфуванні новітніх для всієї гами зносостійких композиційних матеріалів. Для забезпечення високих вимог до параметрів якості доцільним є тонке абразивне шліфування композитних поверхонь підшипників ковзання, яке необхідно здійснювати застосовуючи прецизійні шліфувальні верстати типу SS-125 фірми «Werkzojt» (ФPH), абразивні круги з електрокорунда хромчастого 33АМ28СМ1Гл зі змістом у складі абразиву до 2 \% оксиду хрома $\mathrm{CrO}$ та тонкі режими оздоблювального шліфування, а саме: швидкість шліфувального кругу $-\mathrm{V}_{\mathrm{kp}}=45 \mathrm{~m} / \mathrm{c}$; швидкість виробу $-\mathrm{V}_{\mathrm{B}}=45 \mathrm{M} /$ Хв., подача $-\mathrm{S}=20$ мм/хід, глибина різання $-\mathrm{t}=0,020$ мм.

5. Подальші дослідження доцільно виконувати, вивчаючи особливості технологічних процесів тонкого алмазно-абразивного шліфування деталей тертя поліграфічних машин, що були виготовлені з найновітніших матеріалів - таких, як диборид титану, композити типу сапоніт титану та сапоніт алюмінію, порошкових сплавів на основі гідриду титану та боридів цирконію.

\section{Список використаної літератури}

1. Роїк Т. А. Композиційні підшипникові матеріали для підвищених умов експлуатації : монографія / Т. А. Роїк, П. О. Киричок, А. П. Гавриш. - К. : НТУУ «КПІ», 2007. - 404 c.

2. Киричок П. О. Технологія поліграфічного машинобудування : навчальний посібник / П. О. Киричок, Т. А. Роїк, А. В. Шевчук, А. П. Гавриш, О. І. Лотоцька. - К. : НТУУ «КПІ», 2014. - 504 с.

3. Роїк Т. А. Новітні композиційні матеріали деталей тертя поліграфічних машин : монографія / Т. А. Роїк, А. П. Гавриш, П. О. Киричок, Ю. Ю. Віцюк. К. : НТУУ «КПІ», 2014. - 427 с.

4. Аскеров М. Г. Металлополимерные триботехнические материалы : монография / М. Г. Аскеров, Т. А. Роик, А. П. Гавриш. - К. : НТУУ «КПИ», 2015. $-218 \mathrm{c}$

5. Киричок П. О. Фінішне оброблення зносостійких деталей друкарських машин : навчальний посібник / П. О. Киричок, Т. А. Роїк, А. П. Гавриш, А. В. Шевчук, Ю. Ю. Віцюк. - К. : НТУУ «КПІ», 2014. - 554 с.

6. Роїк Т. А. Сучасні системи технологій заготівельного виробництва в машинобудуванні : монографія / Т. А. Роїк, А. П. Гавриш, О. А. Гавриш. - К. : вид-во ЕКМО, 2010. - 210 с.

7. Гавриш О. А. Новітні технології виробництва стандартизованих виробів : монографія / О. А. Гавриш, Ю. Ю. Віцюк, Т. А. Роїк, А. П. Гавриш, С. В. Войтко. - К. : НТУУ «КПІ», 2012. - 204 с.

8. Гавриш А. П. Фінішна алмазно-абразивна обробка магнітних матеріалів : монографія / А. П. Гавриш, П. П. Мельничук. - Житомир : видво Житомирськ. державн. технологічн. ун-ту (ЖДТУ), 2004. - 551 с.

9. Маслов Е. Н. Теория шлифования материалов / Е. Н. Маслов. - М. : Машиностроение, 1974. - 320 с. 
10. Ящерицын П. И. Прогрессивная технология финишной обработки деталей / П. И. Ящерицын. - Минск : Беларусь, 1989. - 312 с.

11. Байкалов А. К. Введение в теорию шлифования / А. К. Байкалов. К. : Наук. думка, 1978. - 207 с.

12. Маталин А. А. Технологические методы повышения долговечности деталей машин / А. А. Маталин. - К. : Техника, 1971. - 144 с.

13. Новиков Н. В. Инструменты из сверхтвердых материалов / под ред. акад. НАН Украины Н. В. Новикова, д.т.н. С. А. Клименко. - М. : Машиностроение, 2014. - 607 с.

14. Лаврименко В. І. Надтверді абразивні матеріали в механообробці : Енциклопедичний довідник під заг. ред. акад. НАН України М. В. Новікова. - К. : вид-во IHМ НАН України, 2013 - 456 с.

15. Основи теорії різання матеріалів : підручник / М. П. Мазур, Ю. М. Внуков, В. Л. Добросюк, В. М. Залога, Ю. М. Новосьолов, Ф. Я. Якубов; під заг. ред. М. П. Мазура. - Львів : Новий світ, 2010. - 423 с.

16. Сверхтвердые материалы. Получение и применение : монография в 6 т. / под общ. ред. акад. Новикова Н. В. - К. : ИСМ им В. Н. Бакуля НАНУ, 2007. - т. 6 : Алмазно-абразивный инструмент / под ред. А. А. Шепелева. $-340 \mathrm{c}$.

17. Синтетические сверхтвердые материалы : монографія в 3 т. / под. общ. ред. Новикова Н. В. - Т. 3 : Приминение синтетических сверхтвердых материалов. - К. : Наукова думка, 1986. - 280 с.

18. Эльбор в машиностроении : монография (В. С. Лысанов, В. А. Букин, Б. А. Глаговский, З. И. Кремень и др. - Под. общ. ред. В. С. Лысанова Л-д. : Машиностроение, 1978. - 280 с.

19. Ильницкий И. И. Колебания в металлорежущих станках и пути их устранения / И. И. Ильницкий. - М. : Машгиз, 1958. - 142 с.

20. Кудинов В. А. Динамика станков / В. А. Кудинов. - М. : Машиностроение, 1967. - 359 с.

21. Новоселов Ю. К. Динамика формообразования поверхностей при шлифовании / Ю. К. Новоселов. - Саратов : изд-во Саратовс. ун-та, 1979. $-231 \mathrm{c}$.

22. Якимов А. В. Оптимизация процесса шлифования / А. В. Якимов. М. : Машиностроение, 1975. - 172 с.

23. Струтинський В. Б. Технологія моделювання динамічних процесів та систем / В. Б. Струтинський, Н. Р. Веселовська. - Вінниця : НТУУ «КПІ», 2007. $-466 \mathrm{c}$.

24. Струтинський В. Б. Математичне моделювання процесів та систем / В. Б. Струтинський. - Житомир : вид-во ЖДТУ, 2001. - 616 с.

25. Горбунов Б. И. Уравновешивающие устройства шлифовальных станков / Б. И. Горбунов, В. Г. Гусев. - М. : Машиностроение, 1976. $167 \mathrm{c.}$.

26. Данильченко Ю. М. Повышение точности вращения высокоскоростных шпиндельних узлов на підшипниках качения / Ю. М. Данильченко, А. М. Фигатнер, В. Б. Бальмонт, С. Е. Бондарь // Станки и инструмент. - 1987. - № 7. - С. 16-18.

27. Денисюк В. Ю. Дослідження динамічних характеристик пружньої системи безцентрово-шліфувального верстату SWaAKM 25/1A під час переривчастого шліфування / В. Ю. Денисюк, Ю. А. Лук'янчук, Ю. С. Лапченко // Наукові нотатки. - вид-во Луцьк. націон. технічн. ун-ту. 2015. - № 50. - C. 48-55.

28. Гавриш А. П. Контроль наклепу деталей тертя поліграфічних машин зі зносостійких композиційних матеріалів за умов надтонкого 
оздоблювально-абразивного оброблення / А. П. Гавриш, Т. А. Роїк, О. В. Зоренко, Ю. Ю. Віцюк, О. С. Хлус // Технологія і техніка друкарства. - 2015. № 3(49). - С. 42-52. - Режим доступу : http://ttdruk.vpi.kpi.ua/article/ view/54869.

\section{References}

1. Roik T. A. Kompozytsiini pidshypnykovi materialy dlia pidvyshchenykh umov ekspluatatsii : monohrafiia / T. A. Roik, P. O. Kyrychok, A. P. Havrysh. - K. : NTUU «KPI», 2007. - 404 s.

2. Kyrychok P. O. Tekhnolohiia polihrafichnoho mashynobuduvannia : navchalnyi posibnyk / P. O. Kyrychok, T. A. Roik, A. V. Shevchuk, A. P. Havrysh, O. I. Lototska. - K. : NTUU «KPI», 2014. - 504 s.

3. Roik T. A. Novitni kompozytsiini materialy detalei tertia polihrafichnykh mashyn : monohrafiia / T. A. Roik, A. P. Havrysh, P. O. Kyrychok, lu. lu. Vitsiuk. K. : NTUU «KPI», 2014. - $427 \mathrm{~s}$.

4. Askerov M. G. Metallopolimernye tribotehnicheskie materialy : monografija / M. G. Askerov, T. A. Roik, A. P. Gavrish. - K. : NTUU «KPI», 2015. - 218 s.

5. Kyrychok P. O. Finishne obroblennia znosostiikykh detalei drukarskykh mashyn : navchalnyi posibnyk / P. O. Kyrychok, T. A. Roik, A. P. Havrysh, A. V. Shevchuk, lu. lu. Vitsiuk. - K. : NTUU «KPI», 2014. - $554 \mathrm{~s}$.

6. Roik T. A. Suchasni systemy tekhnolohii zahotivelnoho vyrobnytstva $v$ mashynobuduvanni : monohrafiia / T. A. Roik, A. P. Havrysh, O. A. Havrysh. K. : vyd-vo EKMO, 2010. - $210 \mathrm{~s}$.

7. Havrysh O. A. Novitni tekhnolohii vyrobnytstva standartyzovanykh vyrobiv : monohrafiia / O. A. Havrysh, lu. lu. Vitsiuk, T. A. Roik, A. P. Havrysh, S. V. Voitko. - K. : NTUU «KPI», 2012. - 204 s.

8. Havrysh A. P. Finishna almazno-abrazyvna obrobka mahnitnykh materialiv : monohrafiia / A. P. Havrysh, P. P. Melnychuk. - Zhytomyr : vyd-vo Zhytomyrsk. derzhavn. tekhnolohichn. un-tu (ZhDTU), 2004. - $551 \mathrm{~s}$.

9. Maslov E. N. Teorija shlifovanija materialov / E. N. Maslov. - M. : Mashinostroenie, 1974. - $320 \mathrm{~s}$.

10. Jashhericyn P. I. Progressivnaja tehnologija finishnoj obrabotki detalej / P. I. Jashhericyn. - Minsk : Belarus', 1989. - 312 s.

11. Bajkalov A. K. Vvedenie v teoriju shlifovanija / A. K. Bajkalov. - K. : Nauk. dumka, 1978. - $207 \mathrm{~s}$.

12. Matalin A. A. Tehnologicheskie metody povyshenija dolgovechnosti detalej mashin / A. A. Matalin. - K. : Tehnika, 1971. - $144 \mathrm{~s}$.

13. Novikov N. V. Instrumenty iz sverhtverdyh materialov / pod red. akad. NAN Ukrainy N. V. Novikova, d.t.n. S. A. Klimenko. - M. : Mashinostroenie, 2014. - $607 \mathrm{~s}$.

14. Lavrymenko V. I. Nadtverdi abrazyvni materialy $v$ mekhanoobrobtsi : Entsyklopedychnyi dovidnyk pid zah. red. akad. NAN Ukrainy M. V. Novikova. K. : vyd-vo INM NAN Ukrainy, 2013 - 456 s.

15. Osnovy teorii rizannia materialiv : pidruchnyk / M. P. Mazur, lu. M. Vnukov, V. L. Dobrosiuk, V. M. Zaloha, lu. M. Novosolov, F. la. Yakubov; pid zah. red. M. P. Mazura. - Lviv : Novyi svit, 2010. - $423 \mathrm{~s}$.

16. Sverhtverdye materialy. Poluchenie i primenenie : monografija $v 6$ t. / pod obshh. red. akad. Novikova N. V. - K. : ISM im V. N. Bakulja NANU, 2007. - t. 6 : Almazno-abrazivnyj instrument / pod red. A. A. Shepeleva. - $340 \mathrm{~s}$. 
17. Sinteticheskie sverhtverdye materialy : monografija $v 3 \mathrm{t}$. / pod. obshh. red. Novikova N. V. - T. 3 : Priminenie sinteticheskih sverhtverdyh materialov. K. : Naukova dumka, 1986. $-280 \mathrm{~s}$.

18. Jel'bor v mashinostroenii : monografija (V. S. Lysanov, V. A. Bukin, B. A. Glagovskij, Z. I. Kremen' i dr. - Pod. obshh. red. V. S. Lysanova - L-d. : Mashinostroenie, 1978. - $280 \mathrm{~s}$.

19. Il'nickij I. I. Kolebanija v metallorezhushhih stankah i puti ih ustranenija / I. I. II'nickij. - M. : Mashgiz, 1958. - 142 s.

20. Kudinov V. A. Dinamika stankov / V. A. Kudinov. - M. : Mashinostroenie, 1967. - $359 \mathrm{~s}$.

21. Novoselov Ju. K. Dinamika formoobrazovanija poverhnostej pri shlifovanii / Ju. K. Novoselov. - Saratov : izd-vo Saratovs. un-ta, 1979. - $231 \mathrm{~s}$.

22. Jakimov A. V. Optimizacija processa shlifovanija / A. V. Jakimov. - M. : Mashinostroenie, 1975. - $172 \mathrm{~s}$.

23. Strutynskyi V. B. Tekhnolohiia modeliuvannia dynamichnykh protsesiv ta system / V. B. Strutynskyi, N. R. Veselovska. — Vinnytsia : NTUU «KPI», 2007. $466 \mathrm{~s}$.

24. Strutynskyi V. B. Matematychne modeliuvannia protsesiv ta system / V. B. Strutynskyi. - Zhytomyr : vyd-vo ZhDTU, 2001. - $616 \mathrm{s.}$

25. Gorbunov B. I. Uravnoveshivajushhie ustrojstva shlifoval'nyh stankov / B. I. Gorbunov, V. G. Gusev. - M. : Mashinostroenie, 1976. - 167 s.

26. Danil'chenko Ju. M. Povyshenie tochnosti vrashhenija vysokoskorostnyh shpindel'nih uzlov na pidshipnikah kachenija / Ju. M. Danil'chenko, A. M. Figatner, V. B. Bal'mont, S. E. Bondar' // Stanki i instrument. — 1987. № $7 .-$ S. $16-18$.

27. Denysiuk V. Iu. Doslidzhennia dynamichnykh kharakterystyk pruzhnoi systemy beztsentrovo-shlifuvalnoho verstatu SWaAKM 25/1A pid chas pereryvchastoho shlifuvannia / V. Iu. Denysiuk, Iu. A. Luk'ianchuk, Iu. S. Lapchenko // Naukovi notatky. — vyd-vo Lutsk. natsion. tekhnichn. un-tu. — 2015. — № 50. - S. 48-55.

28. Havrysh A. P. Kontrol naklepu detalei tertia polihrafichnykh mashyn zi znosostiikykh kompozytsiinykh materialiv za umov nadtonkoho ozdobliuvalnoabrazyvnoho obroblennia / A. P. Havrysh, T. A. Roik, O. V. Zorenko, lu. lu. Vitsiuk, O. S. Khlus // Tekhnolohiia i tekhnika drukarstva. - 2015. - № 3(49). S. 42-52. - Rezhym dostupu : http://ttdruk.vpi.kpi.ua/article/view/54869.

В статье представлены результаты теоретикоекспериментального исследования проблемы улучшения качества поверхностей отверстий износостойких подшипников скольжения из новых высоколегированных композитних материалов, синтезированных на основе использования утилизированных и регенерированных отходов производства деталей из инструментальных сталей и никеля типа 11РЗАМЗФ2, 7ХГ2ВМФ, 5ХВЗМФС, ХН55ВМТКЮ, ХН50ВТФКЮ путем учета динамических колебаний системы "станок-приспособление-инструментдеталь" для условий тонкого абразивного шлифования. Исследованы схемы замкнутой динамической системы шлифовального станка, установлены и рассчитаны 


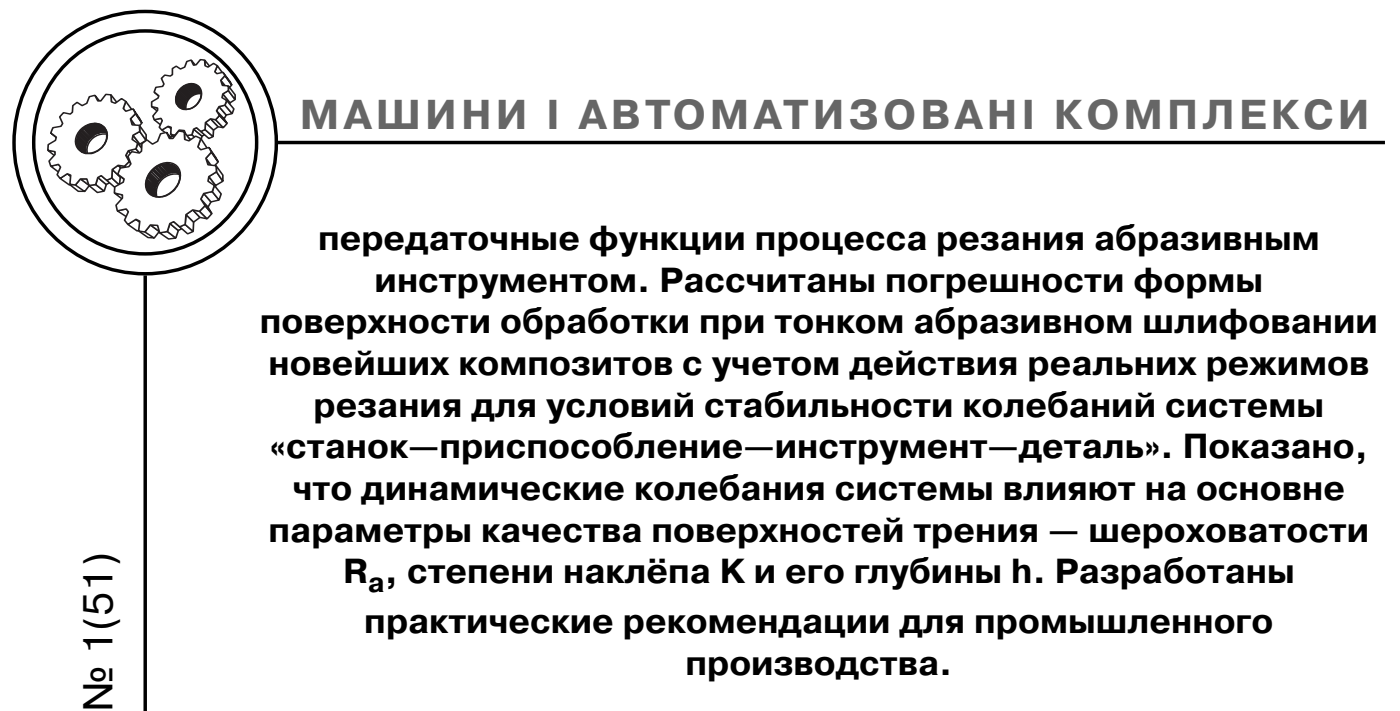

Ключевые слова: тонкое абразивное шлифование; режимы резания; параметры шероховатости поверхности; степень наклепа; композиционные маериалы; динамические колебания системы “станок-приспособление-инструментдеталь»; погрешности поверхности; промышленные рекомендации.

It is presented the results of theoretic and experimental research of the problem of improvement quality of surface of the hole wear resistance slide bearing made from new high-alloy composite materials, which are sinthesized on the base of utilized and regenerated wastes production of parts from instrumental steel and nikel, type 11РЗАМЗФ2, 7ХГ2ВМФ, 5ХВЗМФС, ХН55ВМТКЮ, ХН50ВТФКЮ the way of accounting dynamical vibrations of the system "machine-device-instrument-part" for conditions of thin abrasive grinding have been presented in the article. It was studied the schemes of enclosed dynamical system grinding machine, determine and calculated the transfer functions of cutting process of the abrasive instrument. Calculated the error forms of machining surface at thin abrasive grinding newest compozites with accounting action real parameters of cutting for condition stability system «machine-deviceinstrument-part". I was showen that dynamical vibrations system influence on the primary parameters of quality friction sur-

faces - the roughness $R_{a}$, degree of cool working $K$ and his

depth $h$. Develop the practice recomendations for industrial production.

Keywords: thin abrasive grinding; parameters of cutting; parameters of roughness; degree of cool working; composite materials; dynamical vibrations system «machine-device-instrument-part"; error surfaces; industrial recomendations. 